\title{
Al 6082 and Al 7075 alloys \\ under the modified low-cycle fatigue test
}

\section{Stopy Al 6082 i Al 7075 \\ w warunkach niskocyklowego badania zmęczeniowego}

\begin{abstract}
This paper discusses the possibility of assessing the quality of materials in terms of their mechanical properties as determined by a modified low-cycle fatigue test applied in these studies. The developed computer program adapted to the needs of an MTS universal testing machine is described, as are the details of an algorithm used by this program. The compatibility of test results obtained by the two methods (i.e., the standard low-cycle fatigue test [LCF] and its modified original version [MLCF]) has been demonstrated on the samples of selected non-ferrous metals alloys.
\end{abstract}

Keywords: fatigue, mechanical properties, low-cycle fatigue

\section{Streszczenie}

W niniejszej pracy omówiono możliwość oceny jakości materiałów pod względem ich właściwości mechanicznych, w zmodyfikowanej, niskocyklowej próbie zmęczeniowej. Przedstawiono również opracowany program komputerowy dostosowany do potrzeb uniwersalnej maszyny testującej MTS, a także szczegóły algorytmu używanego przez ten program. Zgodność wyników badań uzyskanych za pomocą dwóch metod: klasycznej niskocyklowej próby zmęczeniowej (LCF) oraz wersji zmodyfikowanej (MLCF) wykazano na przykładzie wybranych metali nieżelaznych stopów.

Słowa kluczowe: zmęczenie materiału, właściwości mechaniczne, niskocyklowa próba zmęczeniowa

\section{Introduction}

The versatile applications of cast materials (including alloys of non-ferrous metals) and efforts for their optimal use are reasons why collecting the most comprehensive data on their properties is so important. One of the basic problems in the field of materials

Maria Maj D.Sc. Eng., Associate Professor, Jarosław Piekło D.Sc. Eng.: AGH University of Science and Technology, Faculty of Foundry Engineering, Krakow, Poland; mmaj@agh.edu.pl 
properties is their behavior under the variable and fast-changing loads; i.e., fatigue resistance [1].

Until recently, data on fatigue characteristics was usually collected in the well-known high- and low-cycle fatigue tests (called HCF and LCF, respectively). The authors of [2] investigated the characteristics of cyclic stress, resistance to deformation, and fracture mechanism operating in the 2524 (EN 573) aluminum alloy. Samples of this alloy were cycled at ambient and elevated temperatures using a tensile-compression load at a load factor of 1.0 under strain-controlled conditions above the range of plastic deformation yielding less than $10^{4}$ cycles to failure. The results have shown that the alloy undergoes a combined hardening and softening in both directions; i.e., longitudinal and transverse.

Recently, much attention has been paid to magnesium alloys used in the automotive industry, aerospace, and electronics. This is mainly due to their low weight and high strength-to-weight ratio. For example, in [3], the fatigue behavior of the AZ61 (ASTM) magnesium alloy produced by squeeze casting was investigated. Fatigue tests based on low-cycle fatigue (LCF) were performed on smooth cylindrical samples under strain-controlled conditions. A standard tensile curve was compared with the cyclic stress-strain curve. A comparison made by the authors of [3] allowed them to establish that the tested material showed cyclic hardening throughout the whole period of use. The resulting measurement data was next used in the evaluation of the Manson-Coffin and WöhlerBasquin curves, fitting them with the appropriate functions of regression to determine the fatigue-strength parameters.

In [4], at room temperature, the fatigue properties of the extruded AZ31B (ASTM) magnesium alloy were determined in a strain-controlled tensile-compression test for different total strain amplitudes. The alloy showed an asymmetric sigmoidal ( $\Sigma$ shaped) hysteresis loop due to twinning in compression occurring at the stage of the unloading and disposal of twins during loading. The authors have proven that the amplitude of total strain, asymmetry of the hysteresis loop, amplitude of plastic strain, mean stress, and stress amplitude all increase, while the ratcheting deformation and pseudoelastic modulus decrease. They have also found that, to describe the fatigue life of this alloy, the Coffin-Manson and Basquin relationships hold true [4].

On the other hand, [5] summarizes the results of extensive research conducted by the authors of this work on the resistance to cyclic deformation, low-cycle fatigue life, and fracture mechanism of the three rapidly solidifying magnesium alloys. Samples of magnesium alloy were subjected to cyclic deformation in a fully reversible total strain amplitude, under strain-controlled conditions, above the range of strain amplitudes, which showed fewer than $10^{4}$ cycles to failure. The characteristics of the cyclic deformation resistance and low-cycle fatigue life of alloys were discussed in relation to the alloy composition. It has been proven that all three alloys obey the Basquin and Coffin-Manson relationship of deformation.

Conventional studies of fatigue behavior of the tested materials (the determination of a Wöhler curve) have been known for a long time; unfortunately, they are both 
laborious and time-consuming. One possible means of shortening the testing time is by conducting the test under conditions of quasi-static loads [6-8] and evaluate the fatigue strength from the results obtained as an acceptable level of stress, or as a stress approaching the asymptote of a Wöhler curve (fatigue strength) without the need to plot the curve for stress exceeding the fatigue limit [8-10].

In the present work, studies were conducted in accordance with the MLCF methodology on selected non-ferrous metals alloys; i.e., Al 6082 and Al 7075. A detailed description of the methodology adopted in both the standard low-cycle fatigue test (LCF) and its modified counterpart (MLCF) is comprised in $[8,11]$.

To determine the parameters of a low-cycle fatigue test according to the LCF methodology, 6-10 samples are required - a fact which, besides the previously mentioned long duration of the test, poses problems of interpretation, particularly in the case of structurally heterogeneous materials. It is worth noting that the results of this test are limited to the parameters closely related with the fatigue behavior of the examined material (b, $c, n^{\prime}, K$, and $\varepsilon_{\text {max }}$ ).

Numerous studies conducted on various alloys $[6-8,10]$ have proven that the proposed modified version of the test offers a range of indisputable benefits since, in combination with the static tensile test, the modified low-cycle fatigue test carried out on one sample only allows for the simultaneous determination of several parameters describing the mechanical behavior of material (including material constants) such as: the elastic modulus $-E$ (for different load ranges), Poisson's ratio $-\mu$, the apparent elastic limit $-R_{0.02}$, the apparent limits $-R_{0.05}$ and $R_{0.1}$, the yield strength $-R_{0.2}$ the accommodation limit $-R_{a}$, the estimated value of rotating bending fatigue strength $-Z_{g o}$ elongation $-A_{5}$, material constants determined from the fatigue test at a reduced number of cycles $-b, c, n^{\prime}$, the nominal stress $-K$, the maximum admissible total strain $-\varepsilon_{\max }$ and, of course, the tensile strength $R_{m}$.

The static tensile test combined with the modified low-cycle fatigue test uses positive tensile cycles extending from a near-zero stress value to the assumed present value, between which the cyclic loading and unloading is conducted. In a test of this type, it is no longer necessary to use several or even several dozen samples to obtain one result of the measurement, since the stabilization of plastic deformation occurs after a number of cycles lower than the number of cycles resulting in failure (the phenomenon of the so-called accommodation). Owing to this, there is no need to load the sample with the number of cycles leading to failure.

\section{Test stand}

Most of the endurance tests were carried out on a modern testing machine type MTS 810 at a maximum load of $100 \mathrm{kN}$ (Fig. 1).

The MTS 810 testing machine is equipped with a TestStar lls digital controller, which is a fully automated digital control system. It supervises the operation of one channel (the actuator and its associated sensors) in a closed feedback loop. 


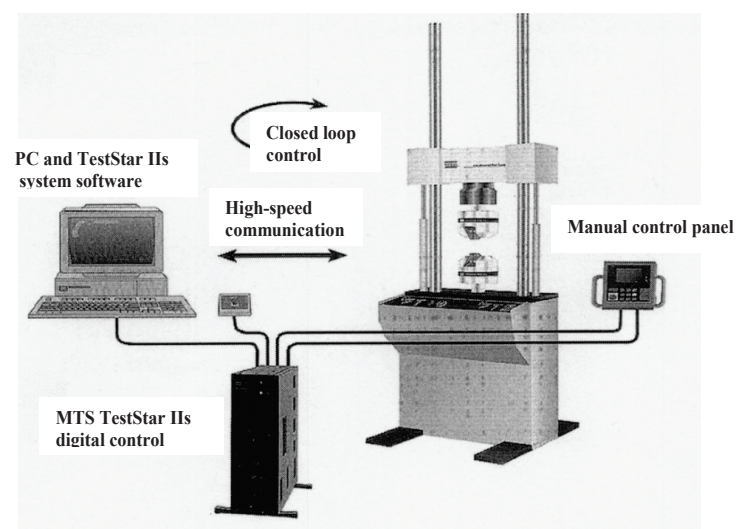

Fig. 1. Testing stand scheme

TestStar Ils uses for system management of a computer graphical environment, which enables programming the test course and data storage. All processes relevant for the proper test control (i.e., the control of actuator, piston movement and data collection) are executed via a digital controller and the proper software.

The digital controller consists of the three basic units:

- Ils TestStar software system, running Microsoft Windows NT on a PC,

- true software based on the latest microprocessor technology, located on a digital controller,

- optional control panel for manual control of hydraulic pressure and actuator position.

\section{Development of MLCF computer program for the universal testing machine}

Adjusting the modified low-cycle fatigue test (originally developed at the Foundry Research Institute by A. Karamara [7] and co-author of this study during research [6, 11, 12] conducted on an INSTRON 1273 testing machine) to the operating conditions of a modern MTS 810 testing machine required two relatively labor-intensive stages.

The first stage used the programmatic performance of the machine equipped with a modern TestStar Ils control system and included the development of a program allowing control of the testing machine operation performed in such a way as to enable the cyclic loading and unloading of the sample in "packages" of 20 cycles (under increasing stress ranges) until rupture. All of the test data was stored in Excel spreadsheets, where they were subjected to further processing, finally resulting in a graph of sample loading plotted in the selected coordinate system, preferably using a stress-strain system $(\varepsilon=\Delta \mathrm{l} / \mathrm{I})$ for the purpose of this work. 
The second stage comprised the step-by-step development of an algorithm for the analysis of data obtained in a static tensile test based on a modified low-cycle fatigue test (MLCF), and the development of an algorithm for a standard low-cycle fatigue test (LCF), to compare both methods for the reliability of results obtained by MLCF.

\section{Short characteristics of the MLCF calculation algorithm}

The calculation algorithm for MLCF is written in Basic. The analyzed data is stored in text files during the LCF and MLCF fatigue tests performed on an MTS 810 machine. The text files are, in turn, subjected to pre-processing done by the established subroutines in the form of macros in an Excel spreadsheet.

The calculation algorithm is divided into six blocks (steps).

In the first block is downloaded data such as a sample cross-section, the force after each unloading, the maximum loading force for the first and last cycle in every "20-cycle package" (loading-unloading), the displacement corresponding to the maximum force for the first and last cycle in every "package," and finally the displacement in the first and last cycle of every "package." Of course, in this block is also calculated the plastic strain obtained in each "package" and stress corresponding to the force of each sample unloading.

In the second block is calculated the elastic modulus (Young's modulus) for the selected range of stresses (i.e., $E_{0}$ (starting), $E_{10}, E_{80}, E_{180}$ ) calculated from equation for the stable mechanical hysteresis loop:

where:

$$
E=\frac{\sigma_{2}-\sigma_{1}}{\varepsilon_{2}-\varepsilon_{1}}
$$

$\sigma_{1}, \varepsilon_{1}$ - the stress and strain (respectively) for the lower tip of the mechanical hysteresis loop,

$\sigma_{2}, \varepsilon_{2}-$ the stress and strain (respectively) for the upper tip of this loop.

In the third block is calculated the yield strength for the strain level of $0.02 ; 0.05$; 0.1 ; and $0.2 \%$; the calculations are made by interpolation (sample deformation measured with an extensometer of a $20 \mathrm{~mm}$ base length), wherefrom follows:

calculation of yield strength $\mathrm{R}_{\mathrm{x}}$ for deformation $\mathrm{x} \%$ :

where:

$$
\begin{aligned}
R_{X} & =N A P_{X D}+C 1 \cdot\left(N A P_{X G}-N A P_{X D}\right) \\
C 1 & =\left(X-O D K_{X D}\right) /\left(O D K_{X G}-O D K_{X D}\right)
\end{aligned}
$$

$\mathrm{NAP}_{\mathrm{XD}}$ - the maximum stress in the package prior to deformation $\mathrm{x} \%$,

$\mathrm{NAP}_{\mathrm{XG}}$ - he maximum stress in the package following deformation $\mathrm{x} \%$,

$O D K_{X D}$ - the strain corresponding to stress $N A P_{X D}$

$\mathrm{ODK}_{\mathrm{XG}}$ - the strain corresponding to stress $\mathrm{NAP}_{\mathrm{XG}}$. 
In the fourth block, the graph shown in Figure 2 is used; it allows for an assessment of rotating bending fatigue strength $Z_{g o}$, necessary to determine the parameters characteristic of MLCF.

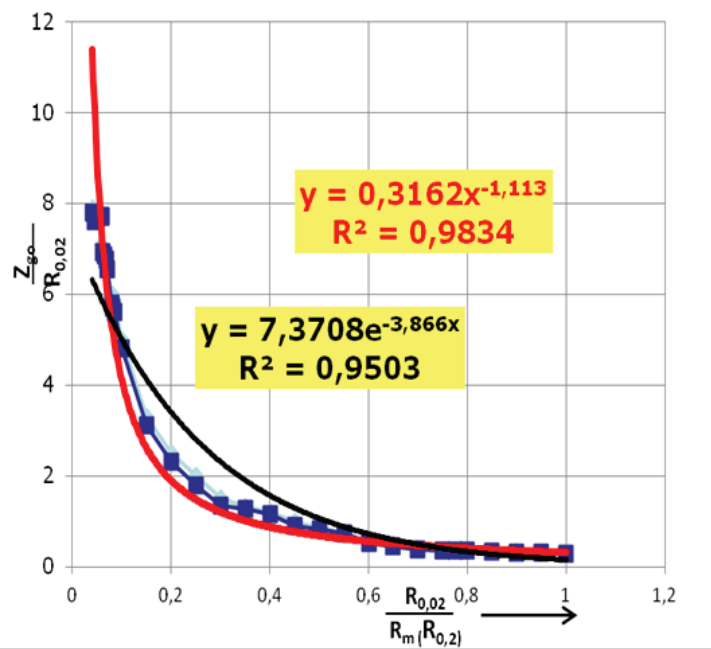

Fig. 2. Curve for fatigue-strength assessment [8]

A program segment for this part of the calculation is shown below:

1. Loading the value of $R_{m}$

2. Determination of $Z_{g o}$.

If there is a limit for the deformation of $0.2 \%$, then

$$
\begin{gathered}
A 0=7.77744901 ; A 1=-66.400118 ; A 2=315.968547 ; A 3=-883.274014 ; \\
A 4=1409.54341 ; A 5=-1176.71248 ; A 6=397.285587 \\
x=G R(1) / G R(4) \\
y=A 0+(A 1 \cdot x)+(A 2 \cdot x \wedge 2)+(A 3 \cdot x \wedge 3)+(A 4 \cdot x \wedge 4)+(A 5 \cdot x \wedge 5)+(A 6 \cdot x \wedge 6) \\
Z_{g o}(1)=G R(1) \cdot y
\end{gathered}
$$

where:

AN - constants in the equation describing the curve for an assessment of fatigue strength $Z_{g o}$

GR (1) - the yield strength corresponding to the deformation of $0.02 \%$, GR (4) - the yield strength corresponding to the deformation of $0.2 \%$. 
If there is no limit for the deformation of $0.2 \%$, then:

$$
\begin{gathered}
x=G R(1) / R_{m} \\
y=A 0+(A 1 \cdot x)+(A 2 \cdot x \wedge 2)+(A 3 \cdot x \wedge 3)+(A 4 \cdot x \wedge 4)+(A 5 \cdot x \wedge 5)+(A 6 \cdot x \wedge 6) \\
Z_{g o}(2)=G R(1) \cdot y
\end{gathered}
$$

In the fifth block is analyzed this part of the algorithm that is responsible for the parameters of the low-cycle fatigue test in both the standard (LCF) and modified (MLCF) forms.

For the standard LCF test, the analysis and calculations were performed according to the guidelines given in [13].

When parameters $\mathrm{b}$ and $\mathrm{c}$ are calculated in the modified MLCF test, the following scheme holds good in this algorithm:

$$
\begin{aligned}
& \mathrm{b}=(\log (\mathrm{R})-\log (\mathrm{Z})) /(\log (20)-\log (\mathrm{N})) \\
& \mathrm{c}=\left(\log \left(\varepsilon_{\mathrm{f}}\right)-\log \left(\varepsilon_{\mathrm{Z}}\right)\right) /(\log (20)-\log (\mathrm{N}))
\end{aligned}
$$

where:

$\mathrm{R}$ - tensile strength $R_{m \prime}$

$Z$ - evaluated fatigue limit $Z_{g o}$

$\mathrm{N}$ - maximum number of cycles corresponding to the fatigue limit of the tested material,

$\varepsilon_{\mathrm{f}}$ - strain corresponding to the tensile strength,

$\varepsilon_{\mathrm{z}}$ - strain corresponding to the fatigue limit evaluated in the rotating bending test.

Then, the admissible total strain is calculated for the number of cycles corresponding to the fatigue limit of tested material $\varepsilon_{\max }$.

$$
\left.\varepsilon_{\max }=[(R / E) \cdot N \wedge b)+\left(\varepsilon_{\mathrm{f}} \cdot N \wedge \mathrm{C}\right)\right]
$$

The last block in the algorithm is for calculating the accommodation limit $R_{a}$; i.e., the largest stress where the stabilization of plastic strain no longer occurs.

This part of the algorithm is mainly for loading the values of plastic strain from each "package," calculating the strain increment attributable to a given "package," and calculating the last "package" number for which the condition of the strain increment in a "package" of cycles lower than or equal to 0.1 is satisfied.

\section{Strength test}

Mechanical tests were performed on samples of Al 6082 and Al 7075 alloys. The shape and dimensions of the samples covered by the research are shown in Figure 3 and Table 1. 


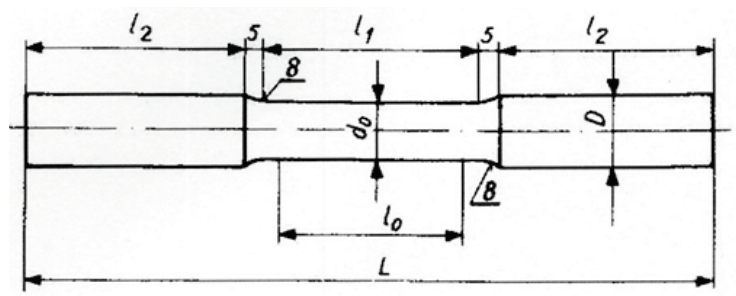

Fig. 3. Dimensions of the test samples

Table 1. Dimensions of the test samples

\begin{tabular}{|c|c|c|c|c|c|c|c|}
\hline$d_{0}[\mathrm{~mm}]$ & $D[\mathrm{~mm}]$ & $I_{0}[\mathrm{~mm}]$ & $I_{1}[\mathrm{~mm}]$ & $I_{2}[\mathrm{~mm}]$ & $L[\mathrm{~mm}]$ & $D[\mathrm{~mm}]$ & $H[\mathrm{~mm}]$ \\
\hline 8 & 10 & 40 & 45 & 30 & 125 & 12 & 16 \\
\hline
\end{tabular}

\section{The results of mechanical tests}

Table 2 compares the selected results of mechanical tests carried out according to the MLCF methodology on two non-ferrous metals alloys; i.e., Al 6082 (1-3) and Al 7075 (4-5).

Table 2. The results of mechanical tests carried out on Al 6082 and Al 7075 alloys.

\begin{tabular}{|c|c|c|c|c|c|c|c|c|c|c|}
\hline No. & $\begin{array}{c}\boldsymbol{R}_{\boldsymbol{m}} \\
{[\mathrm{MPa}]}\end{array}$ & $\begin{array}{c}\boldsymbol{R}_{\mathbf{0 . 0 2}} \\
{[\mathrm{MPa}]}\end{array}$ & $\begin{array}{c}\boldsymbol{R}_{\mathbf{0 . 2}} \\
{[\mathrm{MPa}]}\end{array}$ & $\begin{array}{c}\boldsymbol{R}_{a} \\
{[\mathrm{MPa}]}\end{array}$ & $\begin{array}{c}\boldsymbol{Z}_{\text {go }} \\
{[\mathrm{MPa}]}\end{array}$ & $\boldsymbol{b}$ & $\boldsymbol{c}$ & $\boldsymbol{n}^{\prime}$ & $\begin{array}{c}\boldsymbol{K} \\
{[\mathrm{MPa}]}\end{array}$ & $\varepsilon_{\max } \cdot \mathbf{1 0}^{\mathbf{6}}$ \\
\hline 1 & 380 & 290 & 333 & 363 & 160 & -0.07556 & -0.69330 & 0.033448 & 359.1 & 1812 \\
\hline 2 & 334 & 255 & 283 & 324 & 140 & -0.07538 & -0.75655 & 0.02842 & 311.9 & 1574 \\
\hline 3 & 333 & 257 & 290 & 324 & 141 & -0.07434 & -0.87382 & 0.03546 & 308.9 & 1572 \\
\hline 4 & 660 & 453 & 607 & 642 & 244 & -0.08650 & -0.68818 & 0.02671 & 639.0 & 2527 \\
\hline 5 & 704 & 472 & 600 & 492 & 255 & -0.08826 & -0.43852 & 0.02572 & 653.6 & 2652 \\
\hline
\end{tabular}

Examples of diagrams are presented in Figure 4.

The results of the mechanical tests carried out according to the MLCF methodology (Tab. 2) on alloys of Al 6082 and Al 7075 have shown that the expected values of fatigue strength exponent $b$ and fatigue ductility exponent $c$ fall within the limits reported in the literature; i.e.,

$$
\text { b: from }-0.05 \text { to }-0.15 \text {; c: from }-0.5 \text { to }-0.7
$$




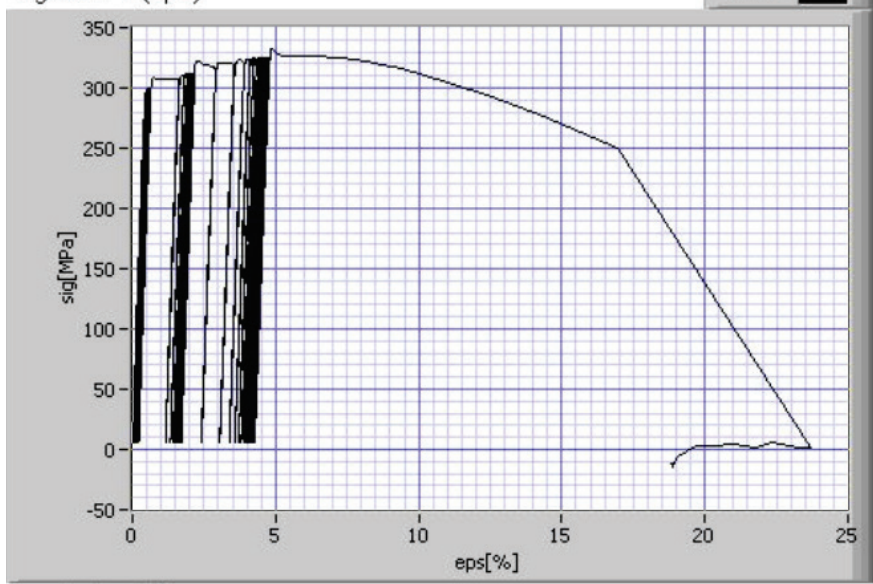

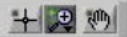

b) Sigma $=f($ eps $)$

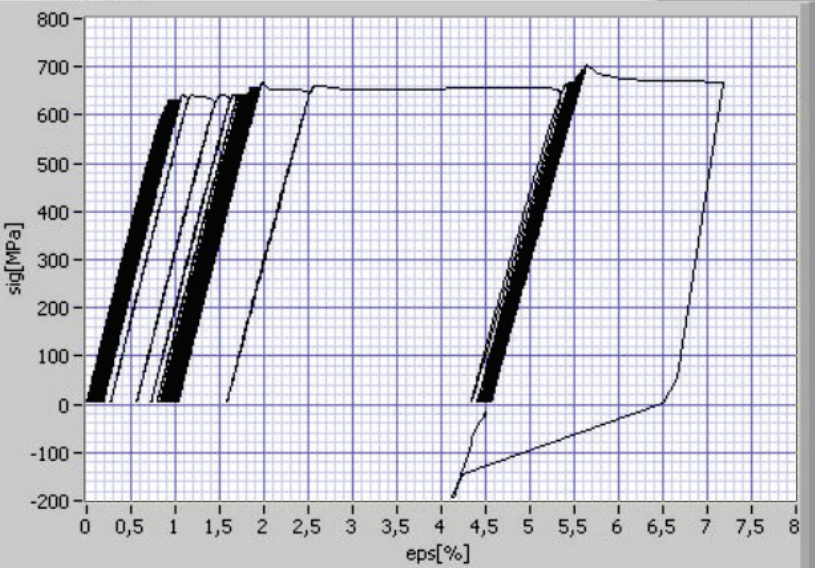

Fig. 4. The $\sigma=f(\varepsilon)$ relationship for: a) Al 6082 alloy; sample no. 3; b) Al 7075 alloy, sample no. 5

For the Al 6082 alloy, the average value of the fatigue strength exponent was $b=-0.07509$, and the average value of the fatigue ductility exponent was $c=-7745$, which was slightly above the upper range of values. In contrast, for the Al 7075 alloy, the average value of the fatigue strength exponent was $b=-0.08738$, and the average value of the fatigue ductility exponent was $c=-0.56335$, which was in the lower range of values. For the Al 6082 alloy, the average value of the maximum admissible total plastic strain $\varepsilon_{\max }$ was $\varepsilon_{\max } \cdot 10^{6}=1652$, and for the Al 7075 alloy, it was $\varepsilon_{\max } 10^{6}=2589$. 
Additionally, to compare the values of the parameters obtained by LCF, Table 3 gives typical fatigue parameters of selected materials such as forged steel, cast aluminum, cast iron, and a component formed by powder metallurgy [8, 14-19].

Table 3. Comparison of selected fatigue parameters of various materials based on literature data

\begin{tabular}{|l|c|c|c|c|c|}
\hline \multicolumn{1}{|c|}{ Fatigue properties } & $\begin{array}{c}\text { Steel } \\
\text { forging } \\
\mathbf{1 1 V 3 7}\end{array}$ & $\begin{array}{c}\text { Aluminum } \\
\text { casting } \\
\text { A356-T6 }\end{array}$ & $\begin{array}{c}\text { Aluminum } \\
\text { casting } \\
\text { A533 }\end{array}$ & $\begin{array}{c}\text { Iron } \\
\text { casting } \\
\mathbf{6 5 - 4 5 - 1 2}\end{array}$ & $\begin{array}{c}\text { Component } \\
\text { formed } \\
\text { by powder } \\
\text { metallurgy }\end{array}$ \\
\hline Fatigue strength exponent $(b)$ & -0.082 & -0.117 & -0.095 & -0.076 & -0.103 \\
\hline Fatigue ductility exponent $(c)$ & -0.791 & -0.610 & -0.690 & -0.771 & -0.530 \\
\hline Cyclic strength coefficient $\left(\mathrm{K}^{\prime}\right)$ & 1269.500 & 430.300 & 940.200 & 649.100 & 2.005 \\
\hline Cyclic strain hardening exponent $\left(\mathrm{n}^{\prime}\right)$ & 0.137 & 0.063 & 0.110 & 0.075 & 0.192 \\
\hline Fatigue ductility coefficient $\left(\mathcal{E}_{\mathrm{f}}^{\prime}\right)$ & 3.032 & 0.094 & 0.350 & 0.864 & 0.198 \\
\hline
\end{tabular}

\section{Materialographic studies by scanning electron microscopy}

SEM fractures of all of the Al 6082 alloy samples (Figs 5-9) fatigue tested by MLCF were qualitatively similar in nature and could be classified as ductile with numerous well-visible characteristic pits marked directly on the photographs (Figs $5 \mathrm{~d}$, 8d). The presence of fatigue striations was not detected in the examined alloys. In all of the Al 7075 alloy samples, fractures obtained by the MLCF fatigue test were also qualitatively similar in nature and could be classified as mixed ductile-brittle fractures with well-visible characteristic pits, cleavage planes, and cracks marked directly on the photographs (Figs 8d, 9c, 9d).
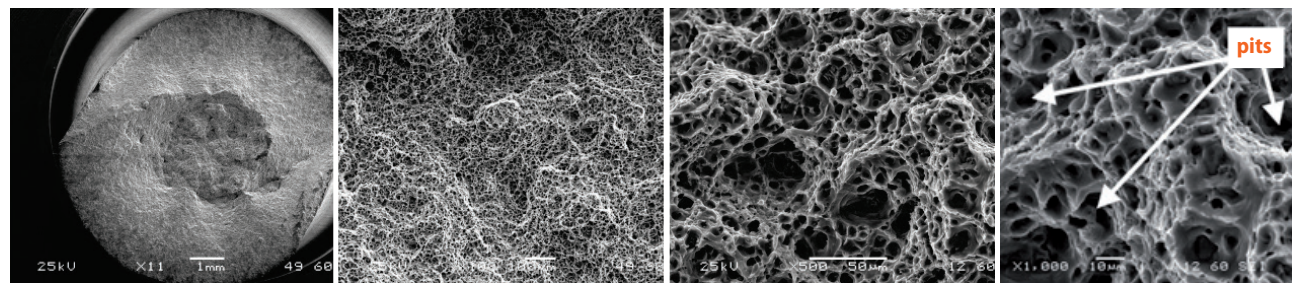

Fig. 5. Al 6082 alloy, sample no. 1: a) 10×, SEM; b) 100x, SEM, c) 500×, SEM; d) 1000×, SEM
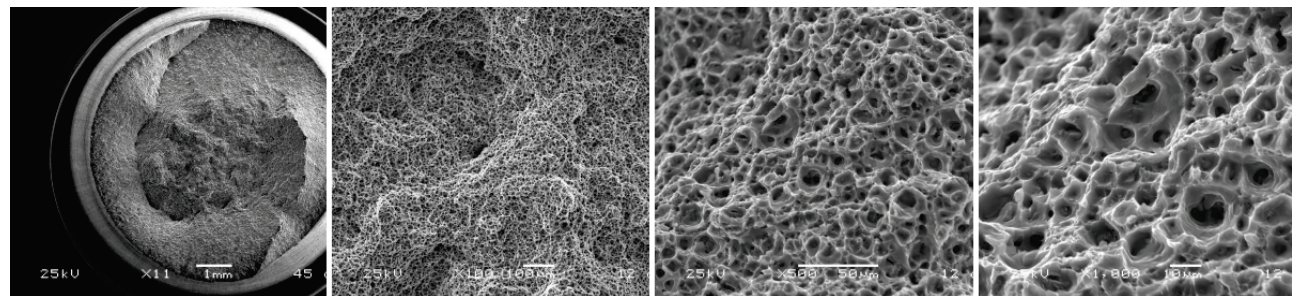

Fig. 6. Al 6082 alloy, sample no. 2: a) 10× SEM; b) 100×, SEM; c) 500×, SEM; d) 1000×, SEM 

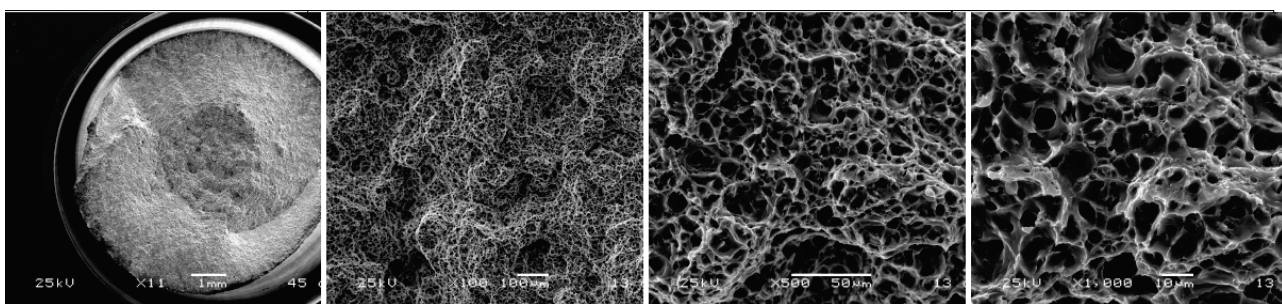

Fig. 7. Al 6082 alloy, sample no. 3: a) 10× SEM; b) 100x, SEM; c) 500x, SEM; d) 1000x, SEM
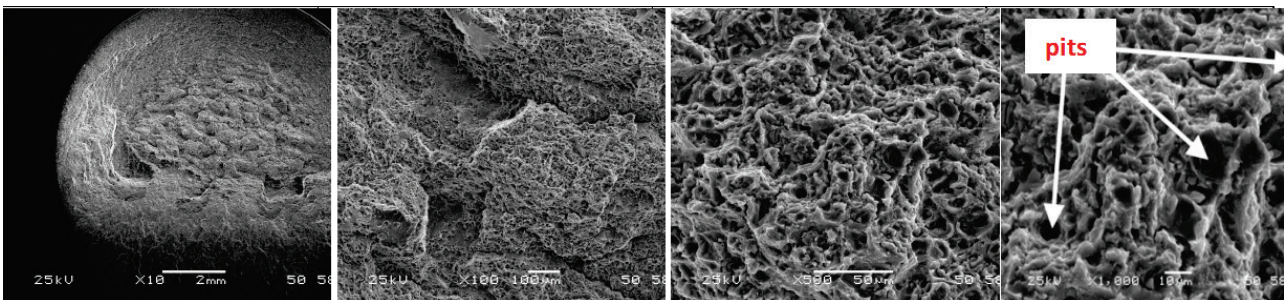

Fig. 8. Al 7075 alloy, sample no. 4: a) 10x, SEM; b) 100x, SEM; c) 500x, SEM; d) 1000x, SEM
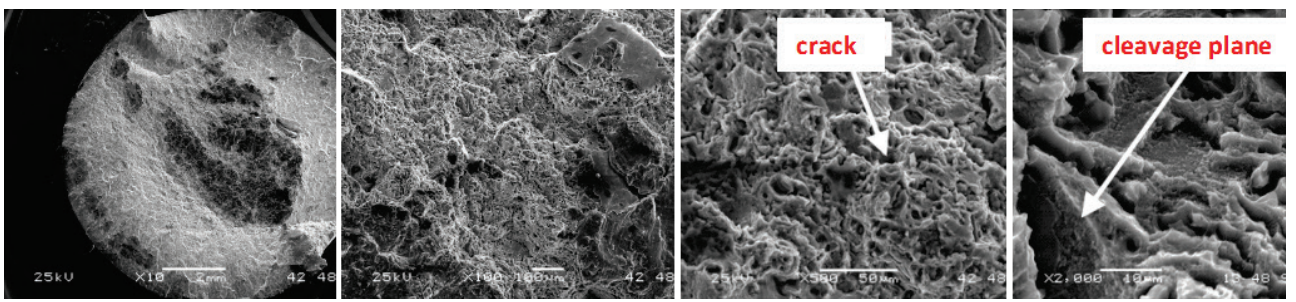

Fig. 9. Al 7075 alloy, sample no. 5: a) 10x, SEM; b) 100x, SEM; c) 500x, SEM; d) 2000x, SEM

\section{Conclusions}

The results obtained suggest the following conclusions:

- the developed computer program for the modified low-cycle fatigue test (MLCF) with an algorithm divided into appropriate programming blocks resulting from the substantive requirements regarding the identification of specific mechanical characteristics ensures reliable and consistent results;

- the original MLCF method used for determining the low-cycle fatigue test parameters provides values falling within the limits reported in the literature. The examined non-ferrous metals alloys are characterized by certain differences in the range of mechanical characteristics obtained. 


\section{References}

[1] Kocańda S., Kocańda A.: Niskocyklowa wytrzymałość zmęczeniowa metali. PWN, Warszawa 1989

[2] Srivatsan T.S, Kolar D., Magnusen P.: Influence of temperature on cyclic response, strain resistance and fracture behavior of aluminium alloy 2524. Materials Science and Engineering A, 314, 1 (2001) 118-130

[3] Zapletal J., Němcová A., Gejdoš P.: [The study of low cyclic behaviour of AZ61 magnesium alloy.] Studie nízkocyklového chování hořčíkové slitiny AZ61, Transactions of the VŠB - Technical University of Ostrava, Mechanical Series, 2, LVI (2010), 225-231

[4] Lin X.Z., Chen D.L.: Strain controlled cyclic deformation behavior of an extruded magnesium alloy. Materials Science and Engineering A, 496 (2008), 106-113

[5] Srivatsan T.S., Chang C.F.: The cyclic strain resistance, fatigue life and final fracture behavior of magnesium alloys. Engineering Fracture Mechanics, 56, 6 (2001), 735-747

[6] Maj M.: Kryteria wytrzymałości eksploatacyjnej odlewów żeliwnych w oparciu o właściwości mechaniczne tworzyw. Doctor thesis, AGH Akademia Górniczo-Hutnicza, Kraków 1984

[7] Karamara A.: Badania materiałowe wybranych gatunków stali niskostopowej w zakresie niskocyklicznych obciążeń zmiennych. Kraków 1980. Praca naukowo-badawcza Instytutu Odlewnictwa, Z-5216/79

[8] Maj M.: Trwałość zmęczeniowa wybranych stopów odlewniczych. Monografia. Wydawnictwo Archives of Foundry Engineering, Katowice-Gliwice 2012

[9] Kocańda S.: Zmęczeniowe niszczenie metali. WNT, Warszawa 1978

[10] Zmęczenie metali. Praca zbiorowa, aut. G. Sines, J.L. Weisman, tłum. A. Turno. WNT, Warszawa 1962

[11] Maj M.: Zastosowanie zmodyfikowanej próby zmęczeniowej do wyznaczania właściwości mechanicznych żeliwa ADI w temperaturze pokojowej i podwyższonej. Projekt badawczy 4T08B00625, Kraków 2005

[12] Gwenaëlle G.: A statistical approach to multi-input equivalent fatigue loads for the durability of automotive structures. Doctor thesis, Chalmers University of Technology and Göteborg University, Göteborg 2006

[13] PN-84/H-04334: Badania niskocyklowego zmęczenia metali

[14] Nguyen Thi Thu Huyen: Effect des heterogenetes microstructurales sur le comportement en fatigue multiaxiale a grand nombre de cycles. Application a l'usinage assiste laser. Doctor thesis, Arts et Métiers ParisTech, Paris 2008

[15] Barrau 0.: Ètude du frottement et de l'usure d'acier à outils de travail à chaud. Doctor thesis, Université de Toulouse, Toulouse 2004

[16] Fares Y.: Dimensionnement en fatigue des assemblages boulonnés à l'aide de critères de fatigue multiaxiale. Doctor thesis, Institut National des Sciences Appliquees de Toulouse, Toulouse 2006

[17] Banvillet A.: Prévision de durée de vie en fatigue multiaxiale sous chargements réels: vers des essais accélérés. Doctor thesis, Ècole Nationale Supérieure d'Arts et Métiers, Centre de Bordeaux 2001

[18] Claudio R.A.: Fatigue behaviour and structural integrity of scratch damage shot peened surface at elevated temperature. Doctor thesis, University of Portsmouth 2005

[19] Maj M., Klasik A., Pietrzak K., Rudnik D.: Modified low-cycle fatigue (LCF) test. Metalurgija. Metallurgy, 54, 1 (2015), s. 207-210 